International Journal of Research in Advent Technology, Vol.7, No.4, April 2019

E-ISSN: 2321-9637

Available online at www.ijrat.org

\title{
Spinel Chemistry an Indicator To The Provenance of Sediments Along The River Cauvery In South India.
}

\author{
Pradeep P. Mujumdar ${ }^{1}$, Prakash Narasimha.K. ${ }^{2}$, Nagendra. ${ }^{3}$, Elango. L ${ }^{4}$ \\ Gobalakrishnan. $\mathrm{N}^{5}$ \\ Department of studies in Earth Science, Center for Advanced Studies in Precambrian Geology, University of \\ Mysore, Manasagangotri, Mysuru- 570 006, Karnataka, India ${ }^{l}$ \\ Department of Geology, Anna University, Chennai-600 025, Tamil Nadu, India ${ }^{2}$ \\ pmujumdar8@gmail.com Mob:+91-8762101972
}

\begin{abstract}
Cauvery river is the third longest river in southern India flowing through the states of Karnataka, Tamil Naduand Kerala and Union Territory of Puducherry and is one of the major source of fresh water for these states. The Cauvery River originates at Talakaveri in the Coorg districtof Karnataka state and joins the bay of Bengal at Poompuharin the Nagapattinam district of Tamil Nadu state covering almost distance of $800 \mathrm{kms}$. The present investigation is focused on the chemistry of the spinel collected from the sediments of river to understand their provenance. The study shows, spinel are derived from both felsic and ultra mafic- mafic source.
\end{abstract}

Keywords: Spinel, Spinel Chemistry, Sediment Provenance,

\section{INTRODUCTION:}

Provenance studies have attracted the geoscientists all over the world. The term provenance is derived from a Latin verb provenire meaning to come forth or to originate. On a broader scale, provenance analysis includes all inquiry that would aid in reconstructing the litho- spheric history of the Earth (Basu, 2003). Provenance studies are windows in to the descent or lineage of the sediment under investigation. Sedimentary provenance studies started in the 19th century with the microscopic investigation of accessory (heavy) minerals of recent sands.

Climate and relief in the source area, the specific types of source lithology, transportation history, size of the grain and setting of the source region controls the provenance of the sediments (Pettijohn et al.,1987). Similarly, whole chemistry of the rock provides insight into the determination of the broader aspects of the provenance, weathering, tectonic setting and diagenesis (Bhatia, 1983, 1985; Whitmore et al., 2004; Verma et al., 2012; Singh, 2013). Identifying the provenance of sediments carried by modern rivers can provide information on earth surface processes and help us to interpret geological history more clearly.

In this work an attempt is made to identify the provenance of the sediments of the river Cauvery in the Karnataka part by using the chemistry of one of the heavy mineral Spinel. Spinel is one of the accessory mineral in the ultramafic and felsic rocks. The evaluation of major element chemistry of spinel is one of the ways to identify the sediment provenance (Dewey and Mange, 1999).

Cauvery River is an easterly flowing river of the Peninsular India that run across four of the southern Indian states i.e. Karnataka, Tamil Nadu, Kerala and Union Territory of Puducherry. The fourth largest river of southern region, begins its $800 \mathrm{~km}$ long journey from the
Western Ghats; traverses through Mysore plateau and finally forms a delta on the eastern coastline of the subcontinent before falling into the bay of Bengal.The Cauvery river basin lies between latitude $10^{\circ} 09^{\prime}$ Nto $13^{\circ} 30^{\prime} \mathrm{N}$ and longitude $75^{\circ} 27^{\prime} \mathrm{E}$ and $79^{\circ} 54^{\prime} \mathrm{E}$. The river basin covers an area of $87,900 \mathrm{~km}^{2}$ and the samples of sediments were collected from 12 locations at regular interval along the course of the river Cauvery (Fig.1).

\section{GEOLOGY OF THE STUDY AREA:}

In the upper reaches, the river flows dominantly through a metamorphic terrane consisting of amphibolite to granulite facies transition zone, whereas in the middle and lower reaches, granulitic rocks dominate the river basin; the uplifted and rejuvenated segment also includes predominantly charnockites and other granulitic rocks Granulite facies rocks mainly includes massive charnockites and amphibolite facies rocks include gneisses with typical gneissic banding.

\section{METHODOLOGY}

Sediment samples were collected at regular intervals of approximately $25 \mathrm{kms}$ distance and the locations as shown in Fig.1. The samples weighing 500g were collected from the river by cone and quartering method and samples were dried and then subjected to sieving using ASTM meshes. The 120 mesh or $0.125 \mathrm{~mm}$ sized samples were subjected to heavy mineral separation by bromoform method. The heavy minerals were collected after filtering with bromoform and dried in the hot air oven at $75^{\circ} \mathrm{C}$ for 4 hours. Then the mineral spinel was separated from the rest with the help of stereo binocular microscope using its physical properties, then the mineral was mounted on the glass slide with the help of epoxy and slightly polished and then subjected for the EPMA (Electron probe micro analysis) at NCEGR lab, 


\section{International Journal of Research in Advent Technology, Vol.7, No.4, April 2019 E-ISSN: 2321-9637 \\ Available online at $w w w . i j r a t . o r g$}

Geological survey of India, Bengaluru, India using CAMECA-SX 100 EPMA instrument to determine the chemistry of spinels.

\section{CHEMISTRY OF SPINEL:}

The spinel was encountered only in two location in overall study area. The spinel was found in the location. 1 Bhagamandala, catchment area and location. 9 Shivanasamudra-middle reach of the river., In the catchment area, the greenish-black grains of Spinel are angular and around Shivanasamudra (location-9), the spinel grains are nearly sub rounded to rounded in shape and are grayish -black in colour. The distribution of number of grains in the sediment sample are represented Fig.2.

Chemistry of the spinel are presented in Table.1. There is extremity in the chemistry of the spinel between the two locations. Spinel shows $\mathrm{Al}_{2} \mathrm{O}_{3}$ values varying from $13.89 \%$ to $58.69 \%, \mathrm{Cr}_{2} \mathrm{O}_{3}$ values range from $7.44 \%$ to $43.12 \%, \mathrm{FeO}$ values are varying between $15.56 \%$ to $34.27 \%$ and $\mathrm{MgO}$ values range from $7.26 \%$ to $18.02 \%$. The chemistry of the spinels of the studied area are compared with the standard chemistry provided by Deer et al., (1996), suggests that the greenish black Al \& Mg rich spinels found in in the catchment area (Location -1) Bhagamandala are derived from felsic source. Whereas the grayish black coloured chrome- rich spinelattribute to meta-igneous source such as metaultramafics belonging to the ancient supracrustal suite.

\section{CONCLUSION:}

The major element chemistry of Spinels serves to determine the provenance, based on the presence of greenish black $\mathrm{Al} \& \mathrm{Mg}$ rich spinels in the catchment area (Location-I), it is suggested that the source rocks are felsic, whereas in Shivanasamudra (location 9)the grayish black coloured chrome rich spinels indicate the source as meta-igneous rock like meta-ultramafic and or mafic rocks belonging to supracrustal suite present in and around the upper reaches of the Cauvery river.

\section{REFERENCES:}

[1] Basu A. "A prospective on quantitative provenance analysis".In R. Valloni and A. Basu (Eds.), Quantitative provenance studies in Italy. Mem.Deserit.dellacarta Geol. dell Itallia, 61, pages 11-22. 2003

[2] Bhatia M R. "Plate tectonics and geochemical composition of sandstones." Journal of Geology, 91, pages 611-627. 1983

[3] Bhatia M R. "Composition and classification of Paleozoicflyschmudrocks of eastern Australia: implications in provenance and tectonic setting interpretations." In Hesse, R. (Ed.), Sedimentology of Siltstone and Mudstone. Sedimentary Geology, 41, pages 249-268. 1985

[4] Deer WA, Howie R A, and Zussman J. "Rock-forming minerals." v. 1A: Orthosilicates (2nd ed.), Geological Society, London. 1996

[5] Dewey J, and Mange M. "Petrography of Ordovician and Silurian sediments in the Western Irish Caledonides: tracers of a short-lived Ordovician continent-arc collision orogeny and the evolution of the Laurentian Appalachian/Caledonian margin." In Mac Niocaill, C.,Ryan, P.D. (Eds.), Continental Tectonics.Geological Society of London, Special Publication, 164, pages 55107. 1999

[6] Pettijohn FJ, Potter P E, and Siever R. "Sand and Sandstone", 2nd ed. Springer, New York. 1987

[7] Pramod Singh, and Rajamani V. "REE geochemistry of recent clastic sediments from the Cauvery floodplains, southern India: Implication to source area weathering and sedimentary processes." GeochemicaetCosmochemicaacta, 65, pages 3093-3108. 2001

[8] Singh BP. "Evolution of the Paleogene succession of the western Himalayan foreland basin." Geosci.Front., 4, pages 199-212. 2013

[9] Verma M, Singh B P, Srivastava A K, and Mishra M. "Chemical behaviour of suspended sediments in a small River draining out of the Himalaya, Tawi River, Northern India: implications on provenance and weathering." Himalayan Geology, 33, pages 1-14. 2012

[10] Whitmore GP, Crook KAW, and Johnson D P. "Grain size control of mineralogy and geochemistry in modern River sediment, New Guinea collision, Papua New Guinea." Sedimentary Geology, 171, pages 129-157. 2004 
International Journal of Research in Advent Technology, Vol.7, No.4, April 2019

E-ISSN: 2321-9637

Available online at www.ijrat.org

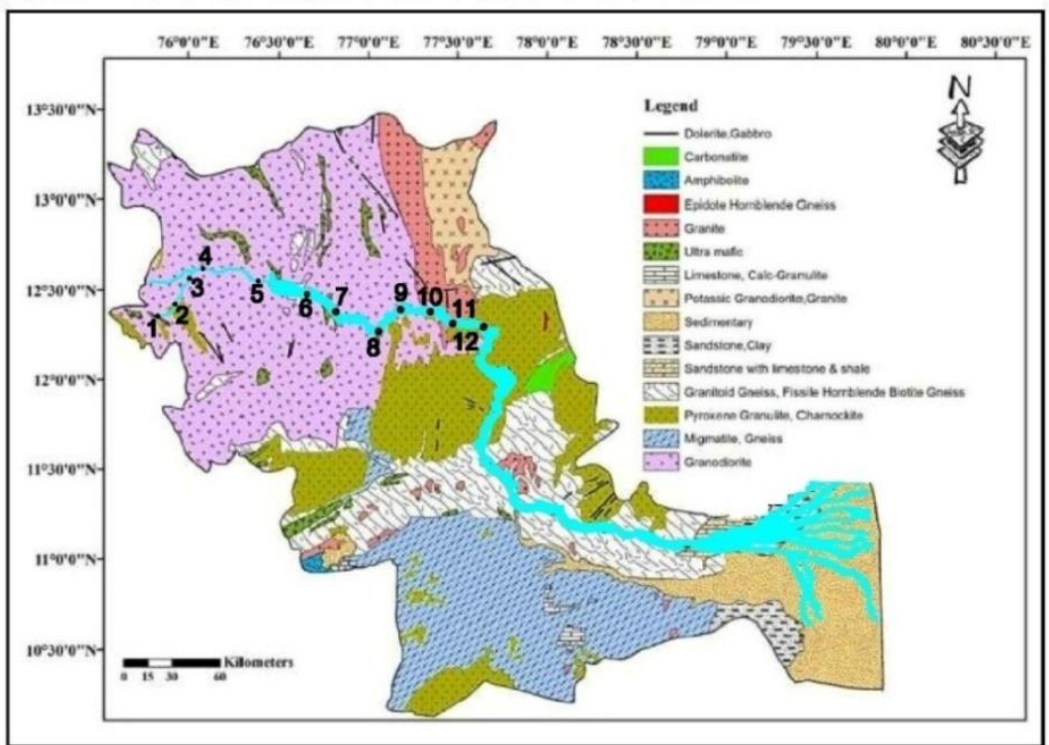

Fig.1. Geology of the Cauvery river basin (After, GSI)

Location 1- Bhagamandala; Location 2- Napoklu; Location 3- Kushalanagara;

Location 4- Rudrapatna; Location 5- K.R. Nagar; Location 6- Balmuri;

Location 7- Mahadevapura; Location 8- T. Narasipura Location 9-Shivanasamudra;

Location 10- Mekedatu; Location 11- Dhanagere; Location 12- Hogenkal

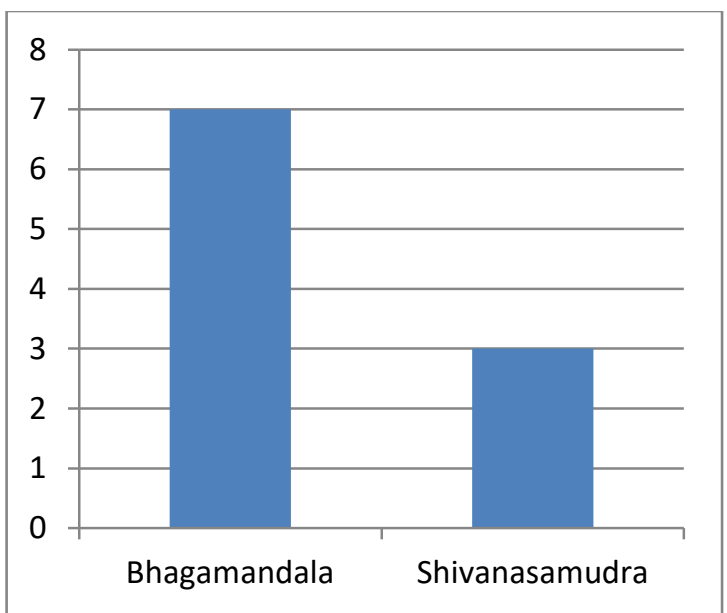

Fig.2 Variation in number of spinel grains with location.

Table.1. Major element chemistry of Spinel

\begin{tabular}{|c|c|c|}
\hline $\mathrm{Wt} \%$ & CS1 & CS9 \\
\hline $\mathrm{SiO}_{2}$ & 0.07 & bld \\
\hline $\mathrm{TiO}_{2}$ & 0.04 & 0.11 \\
\hline $\mathrm{Al}_{2} \mathrm{O}_{3}$ & 58.69 & 13.89 \\
\hline $\mathrm{Cr}_{2} \mathrm{O}_{3}$ & 7.44 & 43.12 \\
\hline $\mathrm{FeO}$ & 15.56 & 34.27 \\
\hline $\mathrm{MnO}$ & 0.15 & 0.39 \\
\hline $\mathrm{MgO}$ & 18.02 & 7.26 \\
\hline $\mathrm{CaO}$ & bld & 0.01 \\
\hline $\mathrm{Na}_{2} \mathrm{O}$ & bld & 0.03 \\
\hline $\mathrm{K}_{2} \mathrm{O}$ & 0.00 & bld \\
\hline $\mathrm{ZrO}_{2}$ & 0.00 & 0 \\
\hline $\mathrm{Total}$ & 100.00 & 99.09 \\
\hline
\end{tabular}

